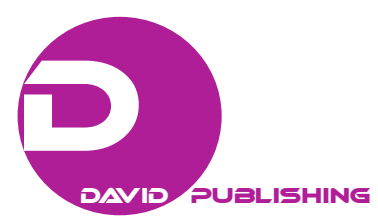

\title{
Genetic Bioengineering in the Achievement of Algae Biofuels and High-Value Bio-products
}

\author{
Şukran Çakır Arıca \\ Iskenderun Technical University, Iskenderun, Turkey
}

\begin{abstract}
The dependence to fossil fuels has increased the amount of greenhouse gases in the atmosphere. That is why, the production of renewable and sustainable biofuels has gained a long-term importance for both scientific and political necessities. In this context, algae are promising in terms of alternative biofuels resources. For this reason, intensive scientific researches have been carried out in recent years on providing optimum efficiency in this regard. Bioengineering is a discipline that applies engineering principles of design and analysis to biological systems and biomedical technologies. Examples of bioengineering research include bacteria or microalgae engineered to produce valuable bioactive chemicals. Microalgae by target gene modification may serve as a promising source for the production of biofuels and bio-based chemicals. A lot of research has been carried out by applying microalgae genomic editing technique with the aim to produce numerous biotechnological products. Some successful previously reported research and production activities are still underway in this area. However, in order to produce the desired products efficiently with manipulated microalgae biorefinery, there is a need to overcome the problem of low biomass production despite high production costs. The aim of this work is to give special attention to the rich potential content of microalgae and to provide information on algal genetic manipulations to increase products by bioengineering methods.
\end{abstract}

Keywords: algal biofuels, algal high-value bio-products, bioengineering, genetic manipulation, microalgae

\section{Introduction}

The world has focused on the discovery of renewable energy sources. Because, fossil fuel reserves which are still supplying a major portion of energy needs, are depleting rapidly by causing ecological damages. In the 21 st century, world is looking for new valuable renewable resources and especially microalgae represent a promising alternative to produce various products with environmentally friendly applications and biotechnogy (Koutra, Economou, Tsafrakidou, \& Kornaros, 2018). Genetic engineering refers to the set of technologies that directly manipulate on an organism's genes, change the genetic make up of cells, and add one or more new traits that are not found in that organism. The aim is to add one or more new traits that are not already found or less in that organism. Microalgae are excellent plants and their biomass is naturally rich in lipids, proteins, carbohydrates, pigments, and some other valuable compounds (Elcik \& Çakmakc1, 2017; Gomaa, Al-Haj, \& Abed, 2016).

Şukran Çakır Arıca, Prof. Dr., Department of Water Resources Management and Organization, Faculty of Marine Sciences and Technology, Iskenderun Technical University, Iskenderun, Turkey.

Correspondence concerning this article should be addressed to Şukran Çakır Arıca, Department of Water Resources Management and Organization, Faculty of Marine Sciences and Technology, Iskenderun Technical University, Iskenderun, Turkey. 
For this reason, some microalgae are considered to be potential sources of future nutrients of biofuels and some valuable natural metabolites. There are some microalgal researches for optimizing the lipid enrichment and the lipid and bioactive compound composition by genetic manipulation. Some genetically engineered strains have been generated to resolve demanding process issues and achieve economic practicality by genetic manipulations.

Genome editing with site-specific nucleases is a genetic engineering technique, skillful of modifying the genomic DNA in a site-specific manner. Different types of this method have been revieved by some scientist (Gaj et al., 2013; Hsu, 2014). To increase productivity of biofuel and bio valuable products of microalgae, genome editing techniques have been used frequently. For example, this method has been studied on microalgae species such as N. gaditana, P. tricornutum, C. reinhardtii, T. pseudonana (Daboussi et al., 2014; Weyman et al., 2015; Shin et al., 2016; Baek et al., 2016; Hopes, Nekrasov, Kamoun, \& Mock, 2016; Jiang \& Weeks, 2017; Ajiawi et al., 2017; Serif, Lepetit, Weißert, Kroth, \& Bartulos, 2017). In addition, some microalgae such as Nannochloropsis as a potential microalgal cell factory for lipid production have received increasing attention in recent years. Lipid production in Nannochloropsis gaditana is doubled by decreasing expression of a single transcriptional regulator (Nguyen, 2016; Wang et al., 2016). It was reported that the ability of algae to grow on wastewaters, converting generated biomass into the pharmaceuticals, biofuels, and food supplements may be a unique and green solution for three major humanian problems such as shortages in food and energy and man-made pollutions (Siddiqui, Miranda, \& Mouradov, 2019). In addition, the cost of biofuels production is still higher than compared to conventional fuel sources. Therefore it was advised by Chia et al. (2018) that integration of biorefinery pathways with biofuels production for the recovery of value-added products such as antioxidants, natural dyes, cosmetics, nutritional supplements, polyunsaturated fatty acids, and so forth could substantially reduce theproduction costs.

\section{Conclusion}

Microalgae are promising micro-organisms for the production of many valuable bioactive chemicals and biofuels. This has led many companies to invest in microalgae to obtain these valuable content. Today, in many parts of the world, there is a large scale plant that produces microalgae for different purposes in indoor and outdoor areas. Especially in biofuel production, as alternatives to fossil fuels, cost reduction studies are being applied to genetic engineering techniques.

It is stated that microalgae production may be an important solution in reducing the dependence on limited fossil fuels, providing sufficient quality nutrients for the increasing world population, and global warming prevention efforts.

Since 1970's, the development in recombinant DNA technology has been the beginning of a new era and revolution in biological research. Nowadays, researchers can now directly edit or modulate the function of DNA sequences and enable them to elucidate the functional organization of the genome at the systems level. With this development, humanity, being careful, can present the possibilities that we can not predict today.

\section{References}

Ajjawi, I., Verruto, J., Aqui, M., Soriaga, L. B., Coppersmith, J., Kwok, K., Peach, L., Orchard, E., Kalb, R., Xu, W., Carlson, T. J., Francis, K., Konigsfeld, K., Bartalis, J., Schultz, A., Lambert, W., Schwartz, A. S., Brown, R., \& Moellering, E. R. (2017). Lipid production in Nannochloropsis gaditana is doubled by decreasing expression of a single transcriptional regulator. 
Nature Biotechnology, 35(7), 647-652.

Baek, K., Kim, D. H., Jeong, J., Sim, S. J., Melis, A., Kim, J. S., Jin, E. S., \& Bae, S. (2016). DNA-free two-gene knockout in Chlamydomonas reinhardtii via CRISPR-Cas9 ribonucleoproteins. Scientific Reports, 6, 30620.

Chia, S. R., Chew, K. W., Show, P. L., Yap, Y. J., Ong, H. C., Ling, T. C., \& Chang, J. S. (2018). Analysis of economic and environmental aspects of microalgae biorefinery for biofuels production: A review. Biotechnology Journal, 13(6), 1700618.

Daboussi, F., Leduc, S., Maréchal, A., Dubois, G., Guyot, V., Perez-Michaut, C., Amato, A., Falciatore, A., Juillerat, A., Beurdeley, M., Voytas, D. F., Cavarec, L., \& Duchateau, P. (2014). Genome engineering empowers the diatom Phaeodactylum tricornutum for biotechnology. Nature Communications, 5, 3831.

Elcik, H., \& Çakmakcı, M. (2017). Production of microalgae and biofuels from microalgae. Journal of the Faculty of Engineering and Architecture of Gazi University, 32(3), 795-820.

Gomaa, M. A., Al-Haj, L., \& Abed, R. M. (2016). Metabolic engineering of cyanobacteria and microalgae for enhanced production of biofuels and high-value products. Journal of Applied Microbiology, 121(4), 919-931.

Hopes, A., Nekrasov, V., Kamoun, S., \& Mock, T. (2016). Editing of the urease gene by CRISPR-Cas in the diatom Thalassiosira pseudonana. Plant Methods, 12(1), 49.

Jiang, W. Z., \& Weeks, D. P. (2017). A gene-within-a-gene Cas9/sgRNA hybrid construct enables gene editing and gene replacement strategies in Chlamydomonas reinhardtii. Algal Research, 26, 474-480.

Koutra, E., Economou, C. N., Tsafrakidou, P., \& Kornaros, M. (2018). Bio-based products from microalgae cultivated in digestates. Trends in Biotechnology, 36(8), 819-833. Retrieved from https://doi.org/10.1016/j.tibtech.2018.02.015Get rights and content

Nguyen, V. (2016). Developing tools to genetically engineer the microalga Nannochloropsis (Master's thesis, NTNU).

Serif, M., Lepetit, B., Weißert, K., Kroth, P. G., \& Bartulos, C. R. (2017). A fast and reliable strategy to generate TALEN-mediated gene knockouts in the diatom Phaeodactylum tricornutum. Algal Research, 23, 186-195.

Siddiqui, M. R., Miranda, A., \& Mouradov, A. (2019). Microalgae as bio-converters of wastewater into biofuel and food. In M. Pannirselvam, L. Shu, G. Griffin, L. Philip, A. Natarajan, and S. Hussain (Eds.), Water scarcity and ways to reduce the impact (pp. 75-94). Part of the Applied environmental science and engineering for a sustainable future. NY: Springer, Cham.

Shin, S. E., Lim, J. M., Koh, H. G., Kim, E. K., Kang, N. K., Jeon, S., Kwon, S., Shin, W. S., Lee, B., Kwon, H., Kim, J., Ye, S. H., Yun, J. Y., Seo, H., Oh, H. M., Kim, K. J., Kim, J. S., Jeong, W. J., Chang, Y. K., \& Jeong, B. (2016). CRISPR/Cas9-induced knock-out and knock-in mutations in Chlamydomonas reinhardtii. Scientific Reports, 6, 27810.

Wang, Q., Lu, Y., Xin, Y., Wei, L., Huang, S., \& Xu, J. (2016). Genome editing of model oleaginous microalgae Nannochloropsis spp. by CRISPR/Cas9. The Plant Journal, 88(6), 1071-1081.

Weyman, P. D., Beeri, K., Lefebvre, S. C., Rivera, J., McCarthy, J. K., Heuberger, A. L., Peers, G., Allen, A. E., \& Dupont, C. L. (2015). Inactivation of Phaeodactylum tricornutum urease gene using transcription activator-like effector nuclease-based targeted mutagenesis. Plant Biotechnology Journal, 13(4), 460-470. 